\title{
Seroprevalence of Corynebacterium pseudotuberculosis and Toxoplasma gondii in sheep in semi-arid region of Ceará state
}

\author{
Gabriela Hémylin Ferreira Moura ${ }^{1}$ Ivana Cristina Nunes Gadelha Lelis ${ }^{2} \mathbb{D}$ \\ Célio Souza da Rocha ${ }^{1,3}$ Ilanna Vanessa Pristo de Medeiros Oliveira ${ }^{1}$ (D) \\ José Artur Brilhante Bezerra ${ }^{1}$ Cecilia Irene Pérez Calabuig ${ }^{1}$ (D) \\ Patrícia Yoshida Faccioli Martins ${ }^{4}$ (D) Raymundo Rizaldo Pinheiro ${ }^{4}$ \\ Maxmiana Mesquita de Sousa ${ }^{4}$ Vanderlan Warlington Souza dos Santos $^{4}$ (D) \\ Antônio Rafael Albuquerque Abreu ${ }^{4}$ João Marcelo Azevedo de Paula Antunes ${ }^{1^{*}(\mathbb{D})}$
}

\author{
${ }^{1}$ Hospital Veterinário Jerônimo Dix-Huit Rosado Maia, Universidade Federal Rural do Semi-árido (UFERSA), 59625-900, Mossoró, RN, \\ Brasil. E-mail: joao.antunes@ufersa.edu.br. "Corresponding author. \\ ${ }^{2}$ Instituto Federal do Ceará, Iguatu, CE, Brasil. \\ ${ }^{3}$ Agência de Defesa Agropecuária do Estado do Ceará (ADAGRI), Fortaleza, CE, Brasil. \\ ${ }^{4}$ Departamento de Sanidade Animal, EMBRAPA Caprinos e Ovinos, Sobral, CE, Brasil.
}

\begin{abstract}
The present study was conducted to investigate in 20 extensive sheep farms for the seroprevalence of Corynebacterium pseudotuberculosis $(n=402)$ and Toxoplasma gondii $(n=228)$. Enzyme-linked immunosorbent assay (ELISA) was used for the detection of antibodies to $C$. pseudotuberculosis/T. gondii. It was observed that $C$. pseudotuberculosis showed the highest prevalence in the region $(34.07 \%)$ with statistically significant presence $(p<0.05)$ in ewes. Antibodies to T. gondii was reported in $14.91 \%$ of the animals studied. About C. pseudotuberculosis/T. gondii coinfection the categories of rams showed significant $(p<0.05)$ differences, suggesting that this gender could perpetuate the diseases in the flocks. It was concluded that the knowledge about the diseases in the region under study would facilitate the execution of prophylactic measures, especially against the diseases that pose risks to the public health and cause damages to the producer. Key words: zoonosis, public health, ram, sheep, ELISA, Toxoplasma gondii, Corynebacterium pseudotuberculosis.
\end{abstract}

Soroprevalência de Corynebacterium pseudotuberculosis de Toxoplasma gondii em ovinos de região semi-árida do estado do Ceará

RESUMO: O presente estudo foi conduzido para investigar a soroprevalência em 20 fazendas de criação extensiva de ovinos quanto à presença de anticorpos para Corynebacterium pseudotuberculosis ( $n=402)$ e Toxoplasma gondii ( $n=228$ ). Ensaio de imunoabsorção enzimático (ELISA) foi utilizado para a detecção de anticorpos contra C. pseudotuberculosis/T. gondii. Observou-se que C. pseudotuberculosis apresentou a maior prevalência na região (34,07\%), com presença estatisticamente significante $(p<0,05)$ nas categorias de ovelha. Anticorpos contra T. gondii foram encontrados em 14,91\% dos animais estudados. Sobre a coinfecção de C. pseudotuberculosis/T. gondii, as categorias carneiro apresentaram diferenças significativas ( $<<0,05)$, sugerindo que esse gênero poderia perpetuar as doenças nos rebanhos. Concluiu-se que o conhecimento sobre as doenças na região em estudo facilitaria a execução de medidas profiláticas, principalmente contra as doenças que apresentam riscos à saúde pública e causam danos ao produtor.

Palavras-chave: zoonose, saúde pública, ovino, ELISA. Toxoplasma gondii, Corynebacterium pseudotuberculosis.

\section{INTRODUCTION}

Brazil has a population of about 18 million sheep. Among these, about $60 \%$ are raised in the Northeast region, especially for meat production. Ceará State is the third largest producer of sheep in Brazil, consisting of approximately 2.3 million animals. In North-eastern Brazil, a high incidence of diseases in sheep is observed, primarily due to improper sanitary management practices for disease prevention and control (PINHEIRO et al., 2009). Poor sanitary conditions may result in serious socioeconomic problems, since many of these diseases are zoonotic (FARIAS et al., 2018).

Among the diseases that need prevention, toxoplasmosis caused by the parasite Toxoplasma gondii is a zoonosis that can cause reproductive disorders, thus affecting the sheep industry in terms of production losses (ANDRADE et al., 2013). Sheep are infected via ingestion of viable oocysts of $T$. 
gondii passed in the faeces of infected felines that are the main reservoirs of infection and the only host that excretes environmentally resistant oocysts (PUGH, 2004; CAVALCANTE et al., 2008). T. gondii causes reproductive failures in ewes. The infection in early pregnancy may result in fetal deaths, while infection in late pregnancy results in weak or even clinically normal lambs. It is also a zoonotic disease causing a variety of conditions in humans, including abortion when they ingest undercooked meat or not pasteurized milk (BENAVIDES et al., 2017).

Caseous lymphadenitis is another disease prevalent in sheep and is an occupational zoonosis in Brazil. It is also termed as pseudotuberculosis, and is caused by Corynebacterium pseudotuberculosis. In small ruminants, a purulent encapsulated abscess in peripheral lymph nodes or internal organs characterized it (CORRÊA et al., 2018). This infection causes considerable economic losses, such as decreased milk/meat production and reduced quality of skin and wool. The transmission of this pathogen is by animal-animal contact, especially through secretions from suppurated abscesses. It can also be transmitted through infected environment, as it is able to penetrate through skin lesions, oral mucosal injuries, and through aerosols from animals with lymphadenitis in the lungs (DOMENIS et al., 2018; CARMINATI et al., 2003). Considered a minor zoonosis, occupationally exposed humans can be infected mainly by direct contact with purulent secretions (DOMENIS et. al., 2018).

The lack of awareness about diseases and their prevention among the producers of Northeastern Brazil might have resulted in a high prevalence of these diseases and their coinfection in sheep. Given the importance of these diseases the objective of this study was to investigate the seroprevalence and their coinfection in sheep of this region.

\section{MATERIALS AND METHODS}

\section{Animals and experimental site}

All (cross breed) animals were from the municipality of Limoeiro do Norte $\left(05^{\circ} 08^{\prime} 44^{\prime \prime} \mathrm{S}, 38^{\circ}\right.$ $05^{\prime} 53^{\prime} \mathrm{W}$ ) in the micro-region of Baixo Jaguaribe in the State of Ceará and were raised extensively without division by age and sex.

The municipality has tropical semi-arid climate (Caatinga Biome) with average temperatures ranging from $22{ }^{\circ} \mathrm{C}$ to $34{ }^{\circ} \mathrm{C}$ degrees and an annual average rainfall of $762 \mathrm{~mm}$. Initially a survey was conducted to verify the sheep herds in the region so that the number of properties for the study, as well as the population of animals could be delineated. The University Federal Rural of Semi-Arid (UFERSA) Faculty of Veterinary Medicine was solicited for veterinary assistance because it is close to the region studied by veterinarians from the State of Ceará who reported recurrent cases of animals with reproductive failures and enlarged or purulent lymph nodes at exhibition in fairs and in the local market. The approximate sample size was calculated according to Thrusfield (2004), with a 95\% confidence level and 5\% accuracy. According to the Agricultural Defense Agency ADAGRI - CE, in 2017 the number of animals in the region was approximately 28,031 sheep heads in 1072 small farms. Then they were randomly selected in order to reach all regions, 20 properties of the municipality. Twenty animals were sampled in each property (except one in which 22 animals were sampled). Within the reality of each property, attempts were made to sample the same amount according to the categories: breeding stock (ram or ewe), gender (male-ram and young males or female- ewes and young females), age group (youngmales and females up to 12 months or adult- ram and ewes) allowing the visualization of the disease across the different categories that constituted the herds under study. To study the seroprevalence of C. pseudotuberculosis ( $\mathrm{n}=402,20$ farms) and $T$. gondii ( $\mathrm{n}=228,19$ farms) ovine blood samples were collected from September 2015 to March 2016, and divided into variables according to the category previously described. For studying the prevalence of T. gondii antibodies, 228 samples (some sera samples have been fully used for C. pseudotuberculosis) from 19 farms were collected.

\section{Collection and packaging of samples}

After asepsis of the jugular region, $5 \mathrm{ml}$ of blood was collected by jugular vein puncture in vacuum tubes without anticoagulants. In the laboratory, after centrifugation at $2500 \mathrm{rpm}$ for 10 minutes, sera obtained were transferred to $2 \mathrm{ml}$ microtubes and stored at $-20{ }^{\circ} \mathrm{C}$ for further analysis.

\section{Serological tests}

Serological tests for antibody determination were carried out at the Laboratory of Clinical Pathology of the Brazilian Agricultural Research Corporation (EMBRAPA Goats and Sheep, Sobral, CE). For the indirect enzyme-linked immunosorbent assay (ELISA) for detection of $C$. pseudotuberculosis antibodies, the methodology described by CARMINATTI et al. (2003), with modifications developed by the Brazilian Agricultural 
Research Corporation (EMBRAPA), was used. The antigen was prepared from the strain 02/2014 (BRM 029971) of C. pseudotuberculosis, isolated from ovine abscess. The positive and negative controls were from EMBRAPA (EMBRAPA Goats and Sheep, Sobral, CE). After the incubation and washing process, the plate was afterward immediately taken to the ELISA reader (Thermo Scientific, Multiscan FC Microplate Photometer N/S 357-906416) and read using a 490-nm filter. The cutoff point was also defined using the ROC curve (Receiver Operator Characteristic). The DO reading values for the test standardized ELISA ranged from 0.072 to 0.250 for uninfected animals and 0.14 to 1.17 for sera from animals known to be infected.

The ELISA was performed for detecting $T$. gondii antibodies, using the methodology described by CAVALCANTE et al. (2008). The procedure was performed in the laboratory of toxoplasmosis of the Federal University of Minas Gerais (ICB-UFMG). The antigen, was prepared using $T$. gondii tachyzoites (RH strain) recovered by lavage of the peritoneal cavity of previously infected Swiss mice using phosphate buffered saline solution (PBS) of $\mathrm{pH}$ 7.2. After the recovery of the tachyzoites, the material was passed purified through $5 \mu \mathrm{m}$ to purify the tachyzoites. The purified tachyzoites were washed and adjust to a final concentration of $1.0 \times 10^{9}$ tachyzoites $/ \mathrm{mL}$ ) after the high speed centrifugation. Cells were then sonicated in an ultrasound device, at a frequency of $40 \mathrm{~Hz}$ to lyse the parasites. The suspension as centrifuged at high speed $(15.000 \mathrm{~g})$ and the supernate was used as an antigen. The cut-off value for each ELISA plate was calculated as the mean absorbance of serum samples obtained from sheep negative for $T$. gondii, plus three standard deviations. The absorbance value provided for each goat was divided by the cut-off value to determine the reactivity index (RI). Sera with
RI values $\geq 1$ were considered positive.

Statistical analysis

For the comparison of the seropositivity frequencies among the categories under study, we used the contingency coefficient calculations with significance level of $5 \%$.

\section{RESULTS}

\section{C. pseudotuberculosis}

Out of the 402 samples analyzed, 34.07\% (137/402) tested positive for antibodies for $C$. pseudotuberculosis. The seroprevalence was higher in ewes (category females, and adult animals, $\mathrm{P}<0.05$ ). Detailed results are shown in table 1 . The positivity was reported in all the farms under study.

\section{T. gondii}

A total of 228 serum samples were analyzed for T. gondii antibodies, and 14.91\% (34/228) were found positive (Table 2 ). No statistically significant difference was reported with respect categories ( $p>$ $0.05)$. Seropositivity was observed in $90 \%(17 / 19)$ of the farms under study.

\section{C. pseudotuberculosis and T. gondii coinfection}

Out of the 228 samples analyzed $8.77 \%$ (20/228) were positive for both C. pseudotuberculosis and $T$. gondii. The seroprevalence was higher in rams $(p<0.05)$. No statistically significant difference was observed with respect to others categories in the prevalence of coinfection (Table 3 ).

\section{DISCUSSION}

The authors are unaware of any reports of these zoonoses in both sheep and humans, to date in the region studied. This make this seroprevalence research relevant because it reports the circulation of

Table 1 - Prevalence of anti-C. pseudotuberculosis antibodies in sheep from the municipality of Limoeiro do Norte, CE, Brazil.

\begin{tabular}{|c|c|c|}
\hline Variables & Number of tested samples $(\%)$ & Number of positive samples (\%) \\
\hline Total population (20 farms) & $402(100 \%)$ & $137(34.07 \%)$ \\
\hline \multicolumn{3}{|c|}{ } \\
\hline Ram & $28(6.96 \%)$ & $9(2.23 \%)$ \\
\hline Ewe & $221(54.97 \%)$ & $94(23.38 \%)^{*}$ \\
\hline
\end{tabular}

*Statistically significant $(\mathrm{p}<0.05)$. 
Table 2 - Prevalence of anti-Toxoplasma antibodies in sheep from the municipality of Limoeiro do Norte, CE, Brazil.

\begin{tabular}{lcc}
\hline Variables & Number of tested samples $(\%)$ & Number of positive samples $(\%)$ \\
\hline Total population (19 farms) & $228(100 \%)$ & $34(14.91 \%)$ \\
\hline$--1 \%$ ) & $21(9.21 \%)$ & $4(1.75 \%)$ \\
Ram & $196(85.96 \%)$ & $28(12.28 \%)$ \\
\hline
\end{tabular}

agents paving way for new research leads on humans. ELISA has been described as a potential diagnostic tool for C. pseudotuberculosis (DORELLA et al., 2006; FARIAS et al., 2018; DOMENIS et al., 2018). Using this technique in Caatinga biome, it was observed the prevalence of $34.07 \%$ (137 animals, Table 1) in the present study. Seropositivity in all farms (20 properties) demonstrated that $C$. pseudotuberculosis is widespread in sheep herds in the area studied.

The $C$. pseudotuberculosis has been detected as an endemic disease in the Brazilian Northeast (Caatinga biome). The bacterial agent is widespread in $88.5 \%$ of the investigated goat properties, including the ones in the Ceará State (FARIAS et al., 2018). CHIRINO-ZÁRRAGA et al. (2009) and FARIAS et al. (2018) reported the highest prevalence of $C$. pseudotuberculosis in ewes, possibly due to their longer stay in the herds. These findings are consistent with the results of the present study where the ewes remain for longer time in the herd and can perpetuate the transmission of $C$. pseudotuberculosis (Table 1). Rams were also positive for $C$. pseudotuberculosis (2.23\%, 9 positives). The authors believed that the $C$. pseudotuberculosis persists in herds due the following reasons: the rams are purchased from herds with unknown health background, and many producers share these rams among themselves, making them potential disseminators of pathogens (TEIXEIRA et al., 2015). The lower percentage of infection in males in the herds could be because the males are slaughtered very young and only few of them are selected for breeding, while females are kept longer in the farms due to their milk and reproductive purposes (FARIAS et al., 2018).

The C.pseudotuberculosis infection among sheep is usually acquired through superficial wounds during common procedures or injuries (DORELLA et al., 2006). It is believed that adult animals show the highest prevalence $(25.43 \%, \mathrm{p}<0.05)$ due to inadequate management, longer duration of exposure to the bacteria, and the type of vegetation present in the Caatinga Biome with predominance of cactus plants, which can cause skin lesions that may contribute to infection by $C$. pseudotuberculosis (SOUZA et al., 2011). The non-division of animals by sex (odds ratio $=4.16$ ) or by age (odds ratio $=6.30$ ), and non-treatment of $C$. pseudotuberculosis lumps prior to spontaneous rupture (odds ratio $=10.34$ ) are the risk factors for the disease in goats (FARIAS et al., 2019). Greater prevalence of the disease in adult animals reflects the chronic and progressive course of infection (DORELLA et al., 2006). The percentage of positive females was higher than the males. It may be due to the periods of immune variation (gestation and lactation) that favor the infections, and the lower

Table 3 - Prevalence of coinfection by T. gondii and C. pseudotuberculosis antibodies in sheep from the municipality of Limoeiro do Norte, CE, Brazil.

\begin{tabular}{|c|c|c|}
\hline Variables & Number of tested samples (\%) & Number of positive samples (\%) \\
\hline Total population (19 farms) & $228(100 \%)$ & $34(14.91 \%)$ \\
\hline ------ & --------------------Category &  \\
\hline Ram & $21(9.21 \%)$ & $4(1.75 \%)^{*}$ \\
\hline Ewe & $196(85.96 \%)$ & $28(12.28 \%)$ \\
\hline
\end{tabular}

Statistically significant $(\mathrm{p}<0.05)$.

Ciência Rural, v.50, n.9, 2020. 
number of males in the study, as they are used for slaughter. In the present study, all the properties had at least three positive animals for C. pseudotuberculosis, suggestive of inadequate sanitary conditions and higher infectivity of the pathogen (GUIMARÃES et al., 2009). Clinical examinations were not the objective of this research that could demonstrate the active disease; however, this seropositivity is important because it suggests infection at some point in the life of these animals and the agent is circulating in the herds. Moreover, the presence of carrier animals is the main source of herd and their identification with subsequent elimination is essential for control and elimination of reinfection (FACCIOLI-MARTINS et al., 2014). The identification by serology (except animals that recovered from diseases and not in preclinical status) before the clinical diseases could be more effective than periodic clinical inspection that cannot reveal subclinical carriers and the seropositive sheep could be disposed as a method for the control of transmission of $C$. pseudotuberculosis.

The higher seroprevalence is important because $C$. pseudotuberculosis is considered a zoonosis in people exposed occupationally to infected animals (ROMERO-PEREZ et al., 2004; JOIN-LAMBERT et al., 2006; HEGGELUND et al., 2015). Although, the focus of this research was not on the clinical aspects, the results demonstrated the importance of seroprevalence for discovery of the pathogen in particular economic areas like Ceará State, where the ovine industry plays an important part. In such regions, the C. pseudotuberculosis could cause considerable economic losses to the sheep breeders (DOMENIS et al., 2018). The identification of potentially infected animals is usually by observing the hypertrophied superficial lymph nodes, this method requires the owners to have adequate experience and technical knowledge and it is not possible to differentiate the characteristic lesions of C. pseudotuberculosis from the abscesses caused by other opportunistic pathogens. Despite being a simple method, palpation cannot disclose asymptomatic carriers, allowing the introduction of these animals in the herds. Thus, other diagnostic methods such as serological tests are necessary as preventive and control method.

The ELISA has been widely used to detect ovine microorganisms, as T. gondii (CLEMENTINO et al., 2007; ANDRADE et al., 2013). It was used in this study for detection of anti-Toxoplasma antibodies. The sheep from the area under study are used for human consumption. This may compromise public health because toxoplasmosis is a zoonosis that affects pregnant women, causing poor fetal formation, abortions, and stillbirths (MORAES et al., 2010; SHAAPAN et al., 2016; BENAVIDES et al., 2017). The prevalence of Toxoplasma in this study was $14.91 \%$ in 228 animals (Table 2). These results are slightly different from those obtained by MORAES et al. (2011) in the state of Maranhão (18.75\%), and by LÚCIO et al. (2017) in Pernambuco (13.60\%). These variations in percentage can be attributed to reasons such as the sample planning, the serological method used, the age of the animals, and the climatic conditions (BUXTON et al., 2006; HUTCHINSON \& SMITH, 2015).

LÚCIO et al. (2017) observed in the state of Pernambuco that ewes are more predisposed to Toxoplasma, probably due to immunosuppression during gestation and lactation. Opportunities of exposure to the infectious agent in females are superior, since the ewes are kept in herds for greater duration. This may be a reason for greater prevalence of disease in ewes. Females have shown greater prevalence of anti-Toxoplasma IgG in another state within the same Caatinga Biome (PINHEIRO et al., 2009). As in others studies, in the present research the ewes showed greater prevalence $(12.28 \%)$ of anti-Toxoplasma IgG. This may be due to ovine Toxoplasmosis being a disease that causes reproductive problems, mainly abortions (ANDRADE et al., 2013) and likely because the ewes are held in the flock for a longer duration getting them infected from the pasture. According to MORAES et al. (2010) the DNA of T. gondii was reported in semen of a small percentage of animals, and due this, there is the possibility of the rams transmit the disease through mating.

OLIVEIRA et al. (2016) and CAMPIGOTTO et al. (2017) observed that the adult animals were more likely to be infected by $T$. gondii, which is consistent with the results of the present study. Approximately $90 \%$ of the analyzed properties had seropositive animals. These results differed from the findings of SALABERRY et al. (2015) where at least one seropositive animal was observed at all the properties. Both the studies have generated a concern regarding this zoonosis, since the prevalence is high in a state that is traditionally a consumer of sheep meat. Our study demonstrated the importance of ewes in the seroprevalence of T. gondii in the herds (Table 2). Ovine Toxoplasmosis is characterized in sheep mainly by episodes of abortion, however, the present study did not touch upon this clinical aspect of the disease or risk factors such as the presence of felines that could be correlated with the higher 
prevalence. In the same state where our research was performed, another study revealed that the number of cats was a risk factor for $T$. gondii infection in goat herd (CAVALCANTE et al., 2008).

According to DOMENIS et al. (2018), coinfection with pulmonary pathogens (nematodes and or Pasteurella) are a probable complicating or debilitating factor in Caseous Lymphadenitis. However, in this study we described the first case of coinfection of $C$. pseudotuberculosis and T. gondii in sheep from properties in a municipality in the State of Ceará (semi-arid region, Caatinga Biome), Brazil (Table 3). Out of the 228 samples tested for both diseases, 34 (14.91\%) had coinfections. The maximum number of positive cases were adult animals (Table 3). We believed that, since both $C$. pseudotuberculosis and T. gondii cause chronic diseases, they affected a smaller percentage the young animals. According to CAVALCANTE et al. (2008) a longer exposure to different risk factors may account for the greater prevalence of toxoplasmosis what we may presume almost the same for the other chronic diseases studied caused by C. pseudotuberculosis.

Coinfection was significant in the rams ( $p$ $<0.05$, Table 3) suggesting that these animals may be responsible for the perpetuation of these diseases (in this case: Caseous Lymphadenitys) in the herd and transmission for the matrices. It is believed that the infection or the coinfection occurs through the exchange or loan of rams among the properties or the managing system that not segregate the different ages. Dissemination of several diseases is seen where the breeders do not maintain adequate sanitation. Then, knowing which age or gender the disease is most prevalent it is also believed that the division/grouping of animals based on age further reduce coinfections (PINHEIRO et al., 2009; SEYFFERT et al., 2010).

T. gondii can disseminate in sheep herds due to pasture contamination and may result in reproductive failures (SHAAPAN, 2016) in extensive breeding with cohabitation with other species such as cats. Conversely C. pseudotuberculosis abscesses and secretions can make the environment more susceptible to infection or coinfections (BUXTON et al., 2006; CAMARGO et al., 2010). According to FARIAS et al. (2008) during the dry season the feeding is based on any food available and goats are raised together with sheep that attracts cats that could infect these animals through oocysts.

Although, the others categories proposed were no suggesting that infection should not be so relevant between ewes and their offspring. Prevalence of these chronic diseases in sheep herds have probably almost no influence on infection of other categories as young animals (except progeny of ewes infected for the first time during pregnancy), and other factors as presence of cats in the farm may important in cases of $T$. gondii infection. However, the consumption of their meat may contain internal abscesses of $C$. pseudotuberculosis or it may be infected with $T$. gondii, which may pose a risk to public health, especially in pregnant women (LIU et al., 2009). The present study identified a coinfection by the presence of antibodies for C. pseudotuberculosis and T. gondii in sheep with a higher prevalence among rams $(p<0.05)$, emphasizing the need for reproductive control (due the possibility of sexual transmission) in these animals, thus avoiding the spread of disease in the herds. We believed that in general the coinfection are underestimated and still require many studies to understand the immune response and the pathogenesis of these coinfection. Our study observed that ewes are more numerous, have a higher frequency of infection (C. pseudotuberculosis/T. gondii/ coinfection), but statistically suggested relevance only in C. pseudotuberculosis seroprevalence, while rams may be important in coinfections. The information about the seropositivity in the herd for the owners demonstrates that they are aware of the presence of C. pseudotuberculosis and Tgondii in their herds, but generally do not implement methods of effective prevention and control of this disease creating a risk of contamination by ignoring the zoonotic potential of these agents.

\section{CONCLUSION}

Although, this research seems to be the first to carry out a regional approach in sheep herd in this region of Ceará, these prevalence calls attention for documenting such a high prevalence in the properties. The observed overall seroprevalences is higher in matrices (for C. pseudotuberculosis, $T$. gondii and coinfection); however, the study revealed that the matrices are significant for antibodies to $C$. pseudotuberculosis, otherwise seroprevalence rates in rams are significant for coinfection suggesting that increasing age of sheep might be associated with seropositivity. This seroprevalence of zoonotic diseases signifies a need for better organization of health control and inspection services. Preventive measures for these diseases, such as the division of animals by age, clinical examinations, serological tests, and disposal of seropositive animals should be routinely included in these properties.

\section{ACKNOWLEDGEMENTS \\ Gratitude for the Master's scholarship from Coordenação de Aperfeiçoamento de Pessoal de Nível Superior}

Ciência Rural, v.50, n.9, 2020. 
(CAPES) for the postgratuate student (GHFM). We are very grateful to all the co-authors. The research would like to thanks to EMBRAPA for its collaboration in relation to serological tests.

\section{DECLARATION OF CONFLICTS OF INTERESTS}

The authors declare no conflict of interest. The founding sponsors had no role in the design of the study; in the collection, analyses, or interpretation of data; in the writing of the manuscript, and in the decision to publish the results.

\section{AUTHORS' CONTRIBUTIONS}

All authors contributed equally for the conception and writing of the manuscript. Material preparation, data collection and analysis were performed by GHFM, ICGNL, IVPMO, CZR, JABB, CIPC, PYFM, RRP, MMS, VWSS, ARAA. The first draft of the manuscript was written by JMAP. All authors read and approved the final manuscript.

\section{BIOETHICS AND COMMITTEE APROVAL}

BIOSECURITY

Animal rights were considered in this study and ethical guidelines of institutional animal ethics committee were followed for conducting the experiment through the number No.23091003804/2016-23 (Committee on Ethics and Animal Use from UFERSA)

\section{REFERENCES}

AL-RAWASHDEH, O.F., AL-QUDAH, K.M. Effect of shearing on the incidence of caseous lymphadenitis in Awasi sheep in Jordan. Journal of Veterinary Medicine, v.47, n.4, p.287-293, 2000. Available from: $<$ https://onlinelibrary.wiley.com/doi/epdf/1 0.1046/j.1439-0450.2000.00346.x>. Accessed: May, 08, 2018. doi: $10.1046 / j .1439-0450.2000 .00346 . x$

ANDRADE, M.M. et al. Seroprevalence and risk factors associated with ovine toxoplasmosis in Northeast Brazil. Parasite, v.20, n.20, p.1-5, 2013. Available from: <https://www.parasite-journal.org/ articles/parasite/pdf/2013/01/parasite120024.pdf $>$. Accessed: Jan. 12, 2019. doi: 10.1051/parasite/2013019.

BENAVIDES, J. et al. Ovine toxoplasmosis: A new look at its pathogenesis. Journal of Comparative Pathology, v.157, n.1, p.34-38, 2017. Available from: <https://www.sciencedirect.com/ science/article/pii/S0021997517300920?via\%3Dihub>. Accessed: Jan. 12, 2019. doi: 10.1016/j.jcpa.2017.04.003.

BUXTON, D. et al. Toxoplasmosis: The possibility of vertical transmission. Journal of Small Ruminant Research, v.62, n.1, p.43-46, 2006. Available from: <https://www.sciencedirect.com/ science/article/pii/S0921448805003081>. Accessed: Dec. 12, 2018. doi: 10.1016/j.smallrumres.2005.07.037.

CAMARGO, E.V. et al. Isolamento de Corynebacterium pseudotuberculosis no sêmen de um carneiro na região central do Rio Grande Do Sul. Arquivos do Instituto Biológico, v.77, n.1, p.139-142, 2010. Available from: <http://www.biologico. sp.gov.br/uploads/docs/arq/v77_1/camargo.pdf $>$. Accessed: Sep. $22,2018$.
CAMPIGOTTO, G. et al. Risk factors for Toxoplasma gondii in sheep of southern Brazil. Comparative Clinical Pathology, v.26, n.3, p.631-635, 2017. Available from: <https://link.springer.com/ article/10.1007/s00580-017-2432-4>. Accessed: Jun. 23, 2018. doi: 10.1007/s00580-017-2432-4.

CARMINATI, R. et al. Determinação da sensibilidade e da especificidade de um teste de ELISA indireto para o diagnóstico de linfadenite caseosa em caprinos. Revista de Ciências Médicas e Biológicas, v.2, n.1, p.88-93, 2003. Available from: $<\mathrm{https}: / /$ portalseer.ufba.br/index.php/cmbio/article/view/4256>. Accessed: Oct. 12, 2018. doi: 10.9771/cmbio.v2i1.4256.

CAVALCANTE, A.C.R. et al. Risk factors for infection by Toxoplasma gondii in herds of goats in Ceará, Brazil. Arquivos Brasileiros de Medicina Veterinária e Zootecnia, v.60, n.1, p.36-41, 2008. Available from: <http://www.scielo.br/scielo. php?script $=$ sci $\_$arttext\&pid $=$S0102-09352008000100006\&lng $=$ en\&tlng=en>. Accessed: Jun, 18, 2019. doi: 10.1590/S010209352008000100006

CHIRINO-ZÁRRAGA, C. et al. Diagnosis of caseous lymphadenitis by ELISA in naturally infected goats from Venezuela. Journal of Small Ruminant Research, v.87, n.1, p.92-95, 2009. Available from: <https://www.sciencedirect.com/ science/article/pii/S0921448809002028?via\%3Dihub>. Accessed: Jan. 12, 2019. doi: 10.1016/j.smallrumres.2009.09.031.

CLEMENTINO, M.M. et al. Seroprevalence and Toxoplasma gondii-IgG avidity in sheep from Lajes, Brazil. Veterinary Parasitology, v.146, n.3-4, p.199-203, 2007. Available from: $<\mathrm{https} / / / \mathrm{www}$. sciencedirect.com/science/article/pii/ S0304401707001306?via\%3Dihub>. Accessed: Jan. 13, 2019. doi: 10.1016/j.vetpar.2007.02.036

CORRÊA, J.I. et al. In vivo and in vitro expression of five genes involved in Corynebacterium pseudotuberculosis virulence. AMB Express, v.8, n.89, p.1-9, 2018. Available from: <https://ambexpress.springeropen.com/track/pdf/10.1186/s13568-018-0598-z>. Accessed: Jan. 26, 2019. doi: 10.1186/s13568-018-0598-z.

DOMENIS, L. et al. Caseous lymphadenitis caused by Corynebacterium pseudotuberculosis in alpine chamois (Rupicapra r. rupicapra): a review of 98 Cases. Journal of Comparative Pathology, 161, 11-19, 2018. Available from: $\quad<\mathrm{https}: / /$ www.sciencedirect.com/science/article/pii/ S0021997518300495?via\%3Dihub> Accessed: Jan. 12, 2019. doi: 10.1016/j.jcpa.2018.04.003

DORELLA, F.A. et al. Corynebacterium pseudotuberculosis: microbiology, biochemical properties, pathogenesis and molecular studies of virulence. Veterinary Research, v.37, n.2, p.201-218, 2006. Available from: <https://www.vetres.org/articles/vetres/ abs/2006/02/v6018/v6018.html $>$. Accessed: Feb. 01, 2019. doi: 10.1051/vetres:2005056.

FARIAS, A.M. et al. Serological study on Corynebacterium pseudotuberculosis infection in goats in the Brazilian Northeast using enzyme-linked immunosorbent assay (ELISA-indirect). Pesquisa Veterinária Brasileira, v.38, n.7, p.1344-1350, 2018. Available from: <http://www.scielo.br/scielo.php?script=sci arttext\&pid $=S 0100-736 X 2018000701344 \& \operatorname{lng}=p t \& t \operatorname{lng}=p t>$. Accessed: Jan. 02, 2019. doi: 10.1590/1678-5150-pvb-5282.

FARIAS, A.E.M. et al. Seroepidemiological characterization and risk factors associated with seroconversion to Corynebacterium 
pseudotuberculosis in goats from Northeastern Brazil. Tropical Animal Health and Production, v.51, n.4, p.745-752, 2019 Available from: <https://link.springer.com/article/10.1007\%2 Fs11250-018-1748-7>. Accessed: Jan. 03, 2019. doi: 10.1007/ s11250-018-1748-7.

GUIMARÃES, A. et al. Linfadenite caseosa em rebanhos ovinos no estado de Minas Gerais, Brasil: prevalência e informações de manejo. Ciência Animal Brasileira, 597-602, 2009. Available from: <https://www.revistas.ufg.br/vet/article/view/7865/5688>. Accessed: Jun. 01, 2019.

FACCIOLI-MARTINS, P.Y., Linfadenite caseosa: perspectivas no diagnóstico, tratamento e controle. Sobral: Embrapa Caprinos e Ovinos - Documentos, Embrapa Caprinos e Ovinos, 113. 2014. Available from: $<$ https://ainfo.cnptia.embrapa.br/ digital/bitstream/item/117061/1/CNPC-2014-Linfadenite.pdf>. Accessed: Jan. 22, 2019.

HEGGELUND, L. et al. Corynebacterium pseudotuberculosis pneumonia in a veterinary student infected during laboratory work. Open Forum Infectious Diseases, v.2, n.2, p.1-6, 2015. Available from: <https://academic.oup.com/ofid/article/2/2/ ofv053/1412865>. Accessed: Jan. 12, 2019. doi: 10.1093/ofid/ ofv053.

HUTCHINSON, J.P.; SMITH, P. Seropositivity to Toxoplasma infection in sheep samples submitted to Animal and Plant Health Agency laboratories between 2005 and 2012. Veterinary Records, v.176, n.22, p.573-573, 2015. Available from: <https:// veterinaryrecord.bmj.com/content/176/22/573>. Accessed: Jan. 23, 2019. doi: 10.1136/vr.102114.

JOIN-LAMBERT, O.F. et al. Corynebacterium pseudotuberculosis necrotizing lymphadenitis in a twelve-year-old patient. The Pediatric Infectious Diseases Journal, v.25, n.9, p.848-851, 2006. Available from: <https://insights.ovid.com/crossref? an=00006454-200609000-00021 >. Accessed: Jan.09, 2019. doi: 10.1097/01.inf.0000234071.93044.77.

LIU, Q. et al. Toxoplasma gondii infection in pregnant women in China. Transactions of Royal Society of Tropical Medicine and Hygiene, v.103, n.2, p.162-166, 2009. Available from: <https:// academic.oup.com/trstmh/article/103/2/162/1906119>. Accessed: Jan. 05, 2019. doi: 10.1016/j.trstmh.2008.07.008.

LÚCIO, É.C. et al. Epidemiological analysis of Toxoplasma gondii infection in sheep in the state of Pernambuco, Brazil. Semina, v.38, n.5, p.3059-3068, 2017. Available from: <https://www. uel.br/revistas/uel/index.php/semagrarias/article/view/25540>. Accessed: Jan. 13, 2019. doi: 10.5433/1679-0359.2017v38n $5 \mathrm{p} 3059$.

MORAES, É.P. et al. Toxoplasma gondii detection in the semen of naturally infected sheep. Pesquisa Veterinária Brasileira, v.30, n11, p.915-917, 2010. Available from: <http://www.scielo.br/ scielo.php?script $=$ sci arttext\&pid $=\mathrm{S} 0100-736 \mathrm{X} 2010001100003 \&$ lng $=\mathrm{pt} \& \operatorname{tng}=\mathrm{pt}>$. Accessed: Jan. 30, 2019. doi: 10.1590/S0100736X2010001100003.

MORAES, E.P. et al. Toxoplasma gondii diagnosis in ovine aborted fetuses and stillborns in the State of Pernambuco, Brazil. Veterinary Parasitology, v.183, n.1-2, p.152-155, 2011. Available from: $\quad<$ https://www.sciencedirect.com/science/article/pii/ S0304401711004651?via\%3Dihub>. Accessed: Jan. 30, 2019. doi: 10.1016/j.vetpar.2011.06.023.
OLIVEIRA, F.C. et al. The incidence and productive significance of ovine toxoplasmosis in southern Brazil. Ciência Rural, v.46, n.9, p.1618-1621, 2016. Available from: <http://www.scielo. br/pdf/cr/v46n9/1678-4596-cr-0103 8478cr20151500.pdf>. Accessed: Jan.12, 2019. doi: 10.1590/0103-8478cr20151500.

PINHEIRO, J.W. et al. Prevalence and risk factors associated to infection by Toxoplasma gondii in ovine in the State of Alagoas, Brazil. Parasitology Research. v.105, n.3, p.709-715, 2009. Available from: <https://link.springer.com/article/10.1007\%2 Fs00436-009-1472-3>. Accessed: Jan. 30, 2019. doi: 10.1007/ s00436-009-1472-3.

PUGH, D.G. Sheep and goat clinic. São Paulo: Roca, 2004. 1v.

ROMERO-PEREZ, J.C. et al. Corynebacterium pseudotuberculosis lymphadenitis in a young patient. Revista Clínica Española, v.204, n.7, p.388-389, 2004. Available from: <https://www.ncbi. nlm.nih.gov/pubmed/?term=Corynebacterium + pseudotuberculosi s+lymphadenitis + in $+a+$ young + patient $>$. Accessed: Jan. 30, 2019.

SALABERRY, S.R.S. et al. Prevalence of anti-Toxoplasma gondii antibodies in sheep in Uberlândia municipality, MG. Arquivos do Instituto Biológico, 82, p.01-04, 2015. Available from: $<$ http://www.scielo.br/scielo.php?script=sci_arttext\&pid=S1808$16572015000100320 \& \operatorname{lng}=p t \& \operatorname{lng}=p t>$. doi: $10.1590 / 1808-$ 1657000992013.

SEYFFERT, N. et al. High seroprevalence of caseous lymphadenitis in Brazilian goat herds revealed by Corynebacterium pseudotuberculosis secreted proteins-based ELISA. Research Veterinary Science, v.88, n.1 p.50-5, 2010. Available from: <https://reader.elsevier.com/reader/sd/pii/S003 4528809001581? token $=$ CDE5764E41DA3DA2116CBCD23A 49456DDD30179A57F2A5DD64F1BC71C77E3DB35041AE CBF8ED7F77B577550F35489CF6>. Accessed: Jan. 31, 2019. 10.1016/j.rvsc.2009.07.002.

SHAAPAN, R.M. 2016. The common zoonotic protozoal diseases causing abortion. Journal of Parasitic Diseases, v.40, n.4, p.11161129. Available from: <https://link.springer.com/article/10.1007 \%2Fs12639-015-0661-5>. Accessed: Jan. 30, 2019. doi: 10.1007/ s12639-015-0661-5

SOUZA, M.F. et al. Caseous lymphadenitis in slaughtered hair sheep in northeastern Brazil. Pesquisa Veterinária Brasileira, v.31, n.3, p.224-448, 2011. Available from: <http://www.scielo.br/ scielo.php?script $=$ sci arttext\&pid=S0100-736X2011000300007\& $\operatorname{lng}=$ pt\&tlng $=p t>$. Accessed: Jan. 31, 2019. doi: 10.1590/S0100736X2011000300007.

TEIXEIRA, W.C. et al. Zoosanitary profile of breeding goats and sheep in three mesoregion of Maranhão State, Brazil. Acta Veterinaria Brasilica, v.9, n.1, p.34-42, 2015. Available from: $\quad<$ https://periodicos.ufersa.edu.br/index.php/acta/article/ view/4438/5761>. Accessed: Feb. 02, 2019. doi: 10.21708/ avb.2015.9.1.4438.

TEIXEIRA, W.C. et al. Seroprevalence of Maedi-Visna in sheep flocks State of Maranhão, Brazil. Revista Brasileira de Ciências Veterinárias, v.23, p.42-47, 2016. Available from: <http://doi. editoracubo.com.br/10.4322/rbcv.2016.028>. Accessed: Jan. 23, 2019. doi: $10.4322 /$ rbcv. 2016.028 .

THRUSFIELD, M. Veterinary Epidemiology. São Paulo: Roca, 2004. 1v. 